\title{
Resumption of gonadotrophin release during the post-partum period in suckling and non-suckling ewes
}

\author{
A. Schirar, Y. Cognié*, F. Louault*, N. Poulin*, C. Meusnier, \\ M. C. Levasseur and J. Martinet
}

Laboratoire de Neurobiologie de la Reproduction, INRA, 78350 Jouy-en-Josas, France; and * Station de Physiologie de la Reproduction, INRA, Nouzilly, 37380 Monnaie, France

\begin{abstract}
Summary. The post-partum secretion of LH, FSH and prolactin was monitored in 15 suckling and 6 non-suckling Préalpes du Sud ewes lambing during the breeding season by measuring plasma hormone concentrations daily at $6-\mathrm{h}$ intervals and also weekly at 20 -min intervals for $6 \mathrm{~h}$ from parturition to resumption of regular cyclic ovarian activity. There was a constant phenomenon in the resumption of normal patterns of FSH and LH secretion: there was a rise in FSH values culminating on average on Day 4 post partum and returning subsequently to values observed during the oestrous cycle, and concurrently an increase in the frequency and amplitude of LH pulses more progressive in suckling than in non-suckling ewes which led to an elevation of LH mean concentrations and occurrence of an LH surge. Since neither the FSH secretory pattern nor FSH mean values differed between suckling and non-suckling ewes, the results suggested that LH pulsatile pattern was a major limiting factor for the resumption of normal oestrous cycles. Before regular oestrous cycles resumed other changes in preovulatory $\mathbf{L H}$ surges also occurred: (i) they increased in duration and probably in amplitude; (ii) they were preceded by an acceleration in LH pulse frequency and a large decrease in FSH values as in normal cyclic ewes; and (iii) at least in non-suckling ewes they occurred concurrently with a prolactin surge.
\end{abstract}

Keywords: ewe; post partum; LH; FSH; prolactin; suckling; breeding season

\section{Introduction}

It is reasonable to assume that, in order that oestrus and ovulation may resume after parturition, the release of gonadotrophins must return to levels similar to those observed in cyclic animals. In the ewe, pituitary contents of luteinizing hormone ( $\mathrm{LH}$ ) and follicle-stimulating hormone (FSH) have been reported to decline during gestation and to remain low throughout the early post-partum period (Chamley et al., 1976; Moss et al., 1980; Crowder et al., 1982). Subsequent resumption of reproductive activity has been shown to be preceded by increased pituitary stores of gonadotrophins (Moss et al., 1980; Wise et al., 1986) and by augmentation in plasma concentrations of gonadotrophins. Restall \& Starr (1977) observed a gradual increase in basal peripheral concentrations of $\mathrm{LH}$, indicating a stepwise recovery of pituitary function, and Fitzgerald \& Cunningham (1981) found that plasma concentrations of FSH gradually increased in the first 5-10 days post partum, but that they fluctuated subsequently without relation to the occurrence of ovulation or oestrus or stage of the post-partum period.

Earlier studies in the ewe were unable to relate endocrine changes to the resumption of ovulation and oestrus post partum because the experiments were often conducted during seasonal anoestrus and were too limited (see Wagner \& Oxenreider, 1971; Edgerton, 1980; Wettemann, 1980; Newton \& Edgerton, 1989) to encompass the endocrine mechanisms involved. Therefore, the 
objective of the present work was to undertake a longitudinal study of LH, FSH and prolactin secretion from parturition until the resumption of oestrous cycles in suckling and non-suckling Préalpes du Sud ewes lambing in October. This study gives additional information to a previous one carried out on the same ewes and relating to the resumption of ovarian activity and oestrous behaviour during the puerperium (Schirar et al., 1989a).

\section{Materials and Methods}

The study was conducted on 6 non-suckling ewes whose lambs were removed on Day I after lambing (Day 0 ) and 15 ewes suckling 1 lamb $(N=6), 2$ lambs $(N=6)$ or 3 lambs $(N=3)$. Blood samples were collected into heparinized tubes by jugular venepunctures from all ewes starting 2 or 3 days before parturition until the resumption of regular oestrous cycles. Pre-partum blood samples were collected once daily $(15: 00 \mathrm{~h})$. From Day 1 post partum until the end of experiment (55 days post partum) blood samples were collected at 6-h intervals $(03: 00,09: 00,15: 00$ and 21:00 h). Furthermore, starting on Day 3 post partum serial samples were collected from all ewes at 20-min intervals for $6 \mathrm{~h}$ once a week for 4-7 weeks depending on whether or not the ewes displayed regular oestrous cycles. Samples were centrifuged and plasma stored at $-20^{\circ} \mathrm{C}$ until assayed.

Radioimmunoassays. All samples from one animal were assayed in a single run. Because of the great number of samples, LH concentrations were measured in duplicate in two different laboratories. Samples collected every $6 \mathrm{~h}$ were assayed as described by Pelletier $e t$ al. (1968), and samples collected at 20-min intervals as described by Kann (197la). Both assays used ovine LH-M3 from CNRS (1.8 i.u./mg NIH-LH-SI; M. Jutisz, Gif-sur-Yvette, France) as standard and tracer but the first technique used a specific antibody raised in the rabbit while the second one used an antibody raised in the guinea-pig. The two assays had the same limit of detection $(0.3 \mathrm{ng} / \mathrm{ml})$ and gave identical standard curves. For both assays intra- and inter-assay coefficients of variation (CV) were $<15$ and $<20 \%$, respectively at a B/Bo value of $80-20 \%$.

FSH concentrations were measured in duplicate by an homologous radioimmunoassay using CNRS-FSH P26 (14 i.u./mg NIH-FSH-S3) as standard and HG-FSH-225-226 (36 i.u./mg MIH-FSH-S3) as tracer (Blanc \& Poirier, 1979). Sensitivity of the assay was 0.2 to $0.5 \mathrm{ng} / \mathrm{ml}$. The intra-assay $\mathrm{CV}$ was $<10 \%$ at a $\mathrm{B} / \mathrm{Bo}$ value of $75-15 \%$; inter-assay $\mathrm{CV}$ was $<20 \%$ at a B/Bo value of $60-30 \%$.

Prolactin concentrations were measured in duplicate by an homologous radioimmunoassay using NIH-P-S7 as standard and tracer (Kann, 197lb). Sensitivity of the assay was $0.3 \mathrm{ng} / \mathrm{ml}$. Intra- and inter-assay CVs were $<15$ and $<20 \%$, respectively, at a $\mathrm{B} / \mathrm{Bo}$ value of $80-20 \%$.

Progesterone was measured by radioimmunoassay as described by Palmer \& Jousset (1975). Only concentrations equalling or exceeding $0.5 \mathrm{ng} / \mathrm{ml}$ were considered as an index of luteinization.

Definitions. The preovulatory LH surge was defined as a rise in LH exceeding $10 \mathrm{ng} / \mathrm{ml}$ in two consecutive blood samples taken at 6 -h intervals. The normal oestrous cycle was defined as a cycle in which daily progesterone concentrations of $\geq 0.5 \mathrm{ng} / \mathrm{ml}$ were sustained for $8-15$ days (Schirar et al., 1989a).

Pulses of LH were defined as described by Martin et al. (1983); i.e. (i) both the increase and subsequent decrease in concentration had to exceed the sum of the assay errors (concentration error) fitted for the concentrations at the nadir and peak of the pulse and (ii) the increase had to occupy no more than two sampling intervals and the decline had to begin within two sampling intervals after peak attainment. Concentration error was computed during counting and represented the sum of the sample preparation error for replicate pairs plus the count error plus the error involved in using the calculated standard curve to determine the concentration. Pulse amplitude was calculated by subtracting the concentration at the nadir of the pulse from the peak concentration.

References to a normal 17-day oestrous cycle for the pulsatile LH pattern or FSH profile were based on data collected from 13 cyclic Préalpes du Sud ewes.

Statistics. Unless otherwise stated, all results are given as mean with s.e.m. To analyse LH and FSH data, mean basal levels were first calculated for each ewe and LH values exceeding the $95 \%$ confidence interval of the mean were removed to exclude preovulatory LH surges. The daily mean basal values for groups of ewes were then calculated from daily LH and FSH concentrations (means of up to 4 measurements) for each ewe. The effects of treatment on mean basal concentrations and on parameters of LH pulsatility within and between groups of ewes were tested for statistical significance by analysis of variance using paired comparisons or by the Wilcoxon-Mann-Whitney test. The relationships between the time to onset of the first LH surge or normal oestrous cycle and the increase in plasma FSH concentrations or LH/FSH ratio values were analysed by calculation of the correlation coefficient with or without logarithmic transformation to homogenize variances.

\section{Results}

\section{Changes in LH and FSH secretion from parturition to the first LH surge post partum}

Pattern of $\mathbf{L H}$ secretion. At the end of gestation, plasma LH concentrations were at the limit of detection of the assay. The day after, the mean basal level was low $(0.6 \pm 0.1 \mathrm{ng} / \mathrm{ml})$ and not 
different in suckling and non-suckling ewes. Subsequently daily mean LH values increased more rapidly in non-suckling ewes than in those suckling 2 or especially 3 lambs (Fig. 1). This elevation of mean LH concentrations appeared to result from change in the pulsatile pattern of $\mathrm{LH}$ secretion. On Day 3 post partum LH pulse frequency, but not amplitude, was greater $(P=0.02)$ in nonsuckling than in suckling ewes (Table 1). During the 2 nd week post partum the number and amplitude of LH pulses did not change in non-suckling ewes but in suckling ewes pulse amplitude increased significantly, mainly in those suckling 2 or 3 lambs $(P=0.02)$, and the number of pulses increased just slightly (Table 1). Finally, within the 4 days preceding the first post-partum LH surge, pulsatile LH secretion was not different amongst ewes (Table 1).

Table 1. Effects of suckling on LH pulsatility in ewes

\begin{tabular}{|c|c|c|c|c|}
\hline & \multirow{2}{*}{$\begin{array}{l}\text { Non-suckling } \\
(\mathrm{N}=6)\end{array}$} & \multicolumn{3}{|c|}{ Suckling $(N=15)$} \\
\hline & & 1 lamb & $2-3$ lambs & Total \\
\hline \multicolumn{5}{|l|}{ On Day 3 post partum } \\
\hline No. of pulses $/ 6 \mathrm{~h}$ & $2 \cdot 7 \pm 0.5$ & $1 \cdot 8 \pm 0 \cdot 2$ & $1 \cdot 4 \pm 0 \cdot 3$ & $1.6 \pm 0.2$ \\
\hline Amplitude (ng/ml) & $3.0 \pm 0.7$ & $2 \cdot 2 \pm 0 \cdot 5$ & $1.9 \pm 0.6$ & $2 \cdot 0 \pm 0.4$ \\
\hline Basal level (ng/ml) & $1 \cdot 0 \pm 0 \cdot 3$ & $0 \cdot 8 \pm 0 \cdot 2$ & $0.6 \pm 0.1$ & $0.7 \pm 0.1$ \\
\hline \multicolumn{5}{|c|}{ During the 2 nd week post partum } \\
\hline No. of pulses $/ 6 \mathrm{~h}$ & $2 \cdot 3 \pm 0 \cdot 4$ & $1 \cdot 8 \pm 0 \cdot 3$ & $2 \cdot 0 \pm 0 \cdot 3$ & $1.9 \pm 0.2$ \\
\hline Amplitude $(\mathrm{ng} / \mathrm{ml})$ & $3 \cdot 8 \pm 1 \cdot 1$ & $2 \cdot 3 \pm 0.5$ & $4 \cdot 0 \pm 0.4$ & $3.3 \pm 0.4$ \\
\hline Basal level (ng/ml) & $1 \cdot 3 \pm 0.4$ & $0 \cdot 6 \pm 0 \cdot 1$ & $0 \cdot 6 \pm 0 \cdot 1$ & $0 \cdot 6 \pm 0.1$ \\
\hline \multicolumn{5}{|c|}{ Within 4 days before the first $\mathrm{LH}$ surge } \\
\hline No. of pulses $/ 6 \mathrm{~h}$ & $2 \cdot 7 \pm 0.4$ & $2 \cdot 0 \pm 0 \cdot 0$ & $2 \cdot 1 \pm 0 \cdot 4$ & $2 \cdot 1 \pm 0.2$ \\
\hline Amplitude (ng/ml) & $3 \cdot 2 \pm 0.7$ & $3.2 \pm 0.9$ & $3 \cdot 6 \pm 0.5$ & $3.4 \pm 0.4$ \\
\hline Basal level (ng/ml) & $1 \cdot 1 \pm 0 \cdot 2$ & $0.7 \pm 0.2$ & $0.8 \pm 0.2$ & $0.8 \pm 0.1$ \\
\hline
\end{tabular}

The first post-partum LH surge occurred 7 days earlier in non-suckling ( $10 \pm 2$ days) than in suckling (17 \pm 1 days) ewes. The number of lambs nursed did not influence this interval which was $16 \pm 2,18 \pm 2$ and $16 \pm 2$ days in ewes suckling 1, 2 and 3 lambs respectively. After this first $\mathrm{LH}$ surge, basal LH values were similar in the ewes whatever their physiological status (i.e. suckling or non-suckling).

Pattern of FSH secretion. At the end of gestation mean FSH concentrations varied widely between animals $(3.2-13.7 \mathrm{ng} / \mathrm{ml})$ but did not differ between suckling and non-suckling ewes (Fig. 1). The day after lambing, FSH secretion increased in 20/21 ewes to reach on average 4 days later a high value comparable to that a preovulatory surge of FSH. This increase was roughly linear with a slope which was not different between suckling and non-suckling ewes (range $0 \cdot 108-0 \cdot 381 \mathrm{ng} / \mathrm{ml} /$ $6 \mathrm{~h}$ ). Subsequently FSH concentrations decreased then followed a quite clear wave-like pattern suggesting a 4 6-day rhythm (Fig. 2) comparable to that observed during the normal oestrous cycle (Fig. 3).

When the rate of immediate post-partum increase in FSH was estimated individually for the 20 ewes by the slope of a regression line drawn from parturition to the maximum value reached, this slope was negatively correlated with the interval from parturition to the first $\mathrm{LH}$ surge $(r=-0 \cdot 45$, $P=0 \cdot 044)$. When the increase in FSH was rapid, the interval from parturition to first normal luteal phase was increased ( $r=0 \cdot 45, P=0.036$; Fig. 4).

\section{Pattern of prolactin secretion}

In non-suckling ewes, prolactin values were low by Day 4 post partum and remained at levels similar to those observed in normal cyclic ewes $(20-30 \mathrm{ng} / \mathrm{ml})$ until the end of experiment. In suckling ewes prolactin concentrations remained elevated on Day 4 post partum $(585 \pm 70 \mathrm{ng} / \mathrm{ml})$ 

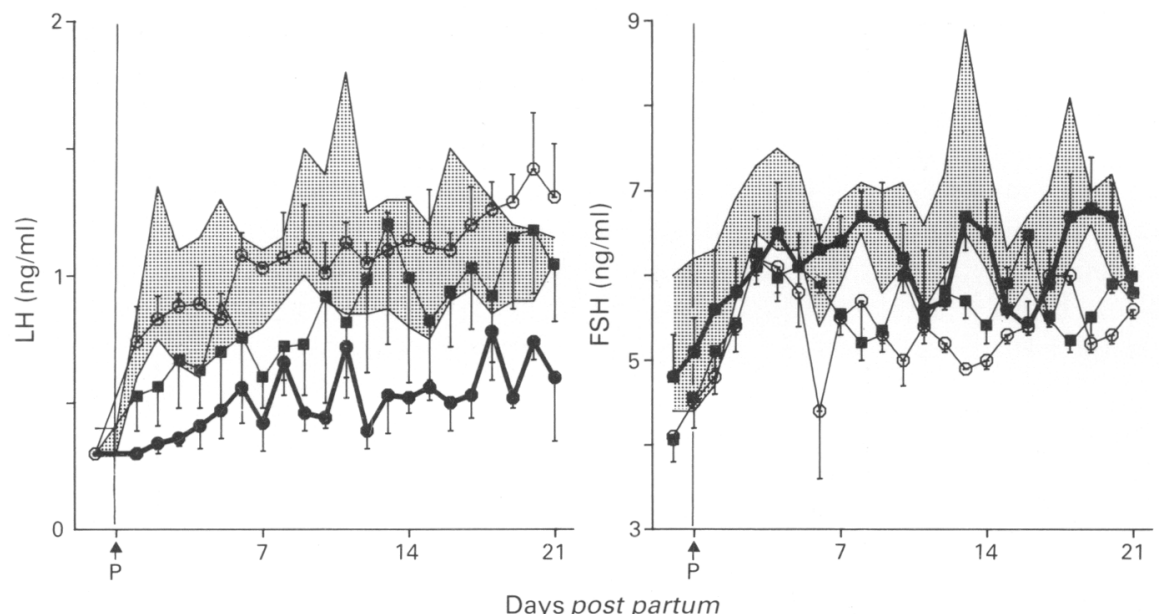

Fig. 1. Daily mean plasma concentrations of LH and FSH before and after parturition (P) in non-suckling ewes (shaded area: mean \pm 1 s.e.m.) and in ewes suckling $1(\mathrm{O}), 2(\boldsymbol{\square}-\boldsymbol{\square})$ and $3(0)$ lambs.

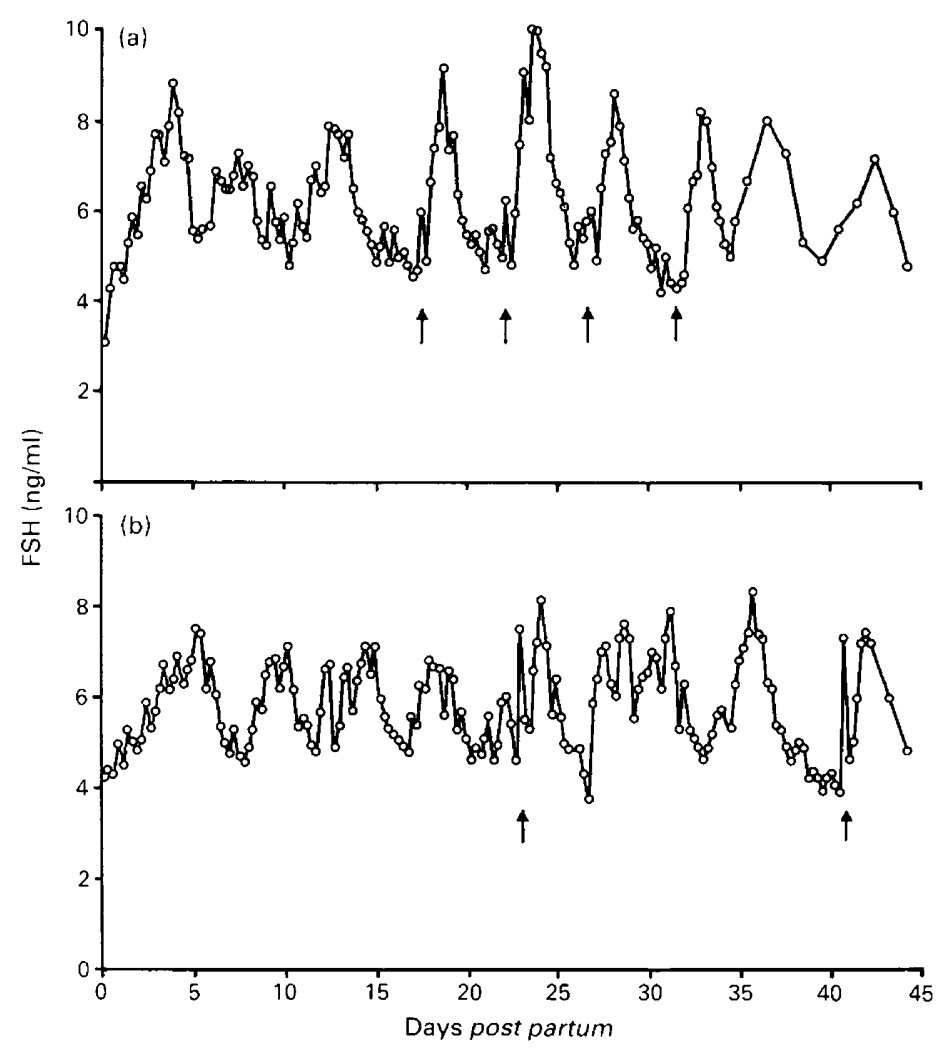

Fig. 2. Profiles of FSH plasma concentrations in 1 representative non-suckling ewe (a) and in 1 representative suckling ewe (b) during the first 45 days post partum. Arrows indicate LH surges. 


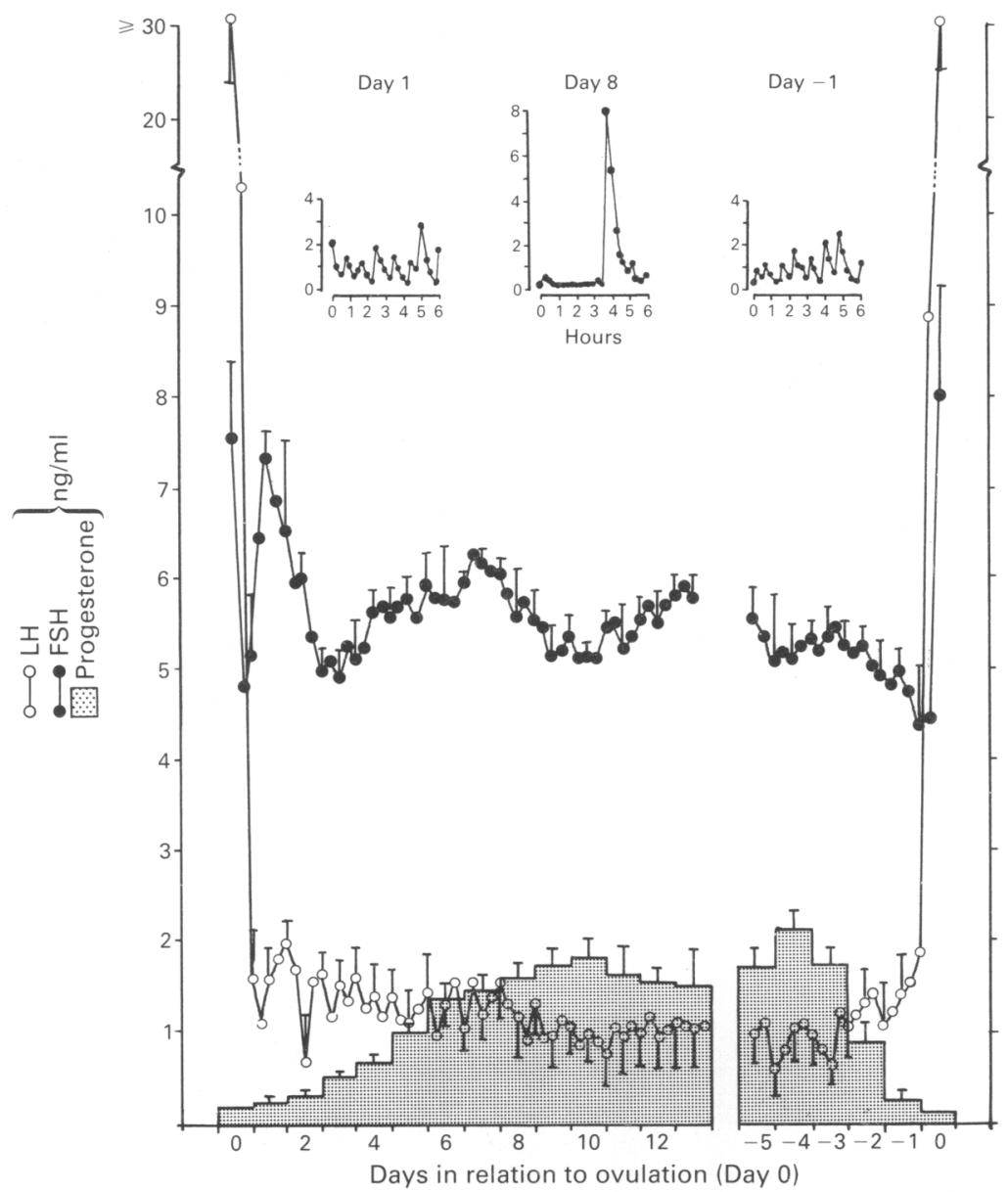

Fig. 3. Mean \pm s.e.m. LH (O), FSH (O) and progesterone (国) plasma concentrations during the normal oestrous cycle $(17 \pm 2$ days $)$ in 13 ewes. Data have been normalized on the $\mathrm{LH}$ peaks. Inserts show the changes in LH pulsatile secretion in 1 ewe on the day indicated.

without any influence of the number of lambs nursed. From the 2 nd week post partum prolactin concentrations decreased progressively to reach $50-100 \mathrm{ng} / \mathrm{ml}$ at the 6 th week (Fig. 5).

\section{Changes in gonadotrophin and prolactin secretion at the establishment of the first normal oestrous cycle}

As reported elsewhere (Schirar et al., 1989a), one or more LH surges (especially in non-suckling ewes) occurred before normal cycles resumed. In the present study the first normal cycle resumed at $29 \pm 5,20 \pm 2$ and $27 \pm 3$ days post partum in non-suckling ewes and in those suckling 1 and $2-3$ lambs, respectively. The first normal cycle preceded by a standing oestrus resumed at $34 \pm 4$, $37 \pm 3$ and $36 \pm 2$ days post partum. Some changes in gonadotrophin and prolactin secretion were associated with the resumption of normal oestrous cycles. The duration (and probably also the amplitude) of the $\mathrm{LH}$ surges was greater $(>12 \mathrm{~h})$. In effect, when by chance the surges started between 09:00 and 15:00 h (during serial sampling) they were no longer detectable at 21:00 $\mathrm{h}$ when they occurred before Day 20 post partum but yet detectable beyond Day 25 . It was only at that time that the LH surges were preceded, within the previous $24-48 \mathrm{~h}$, by very frequent LH pulses of small 


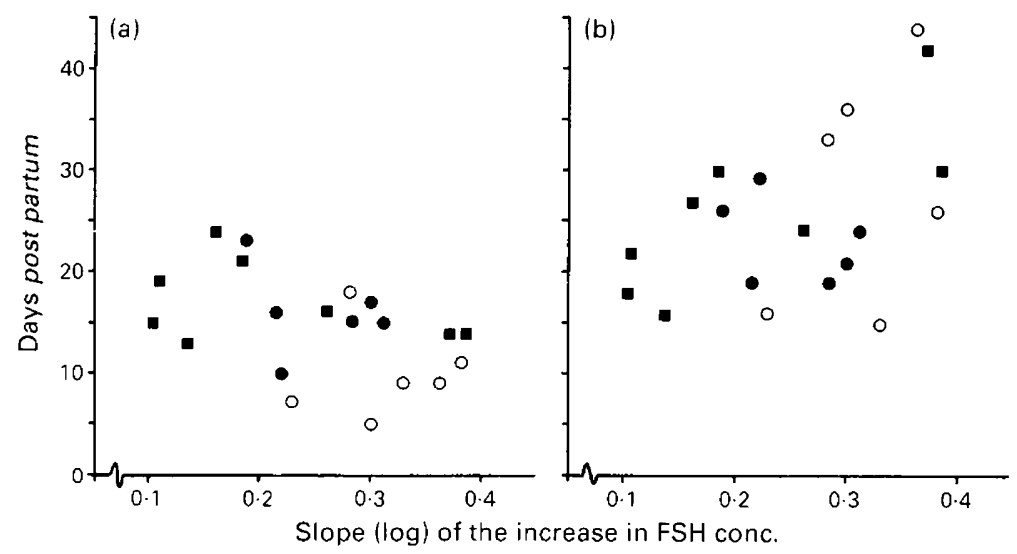

Fig. 4. Correlations between the slope of the increase in FSH plasma concentrations after parturition and the post-partum interval to (a) the first LH surge or (b) the first normal luteal phase in non-suckling ewes $(\bigcirc)$ and in ewes suckling 1 lamb $(\mathbf{O})$ or $2-3$ lambs $(\boldsymbol{\square})$.

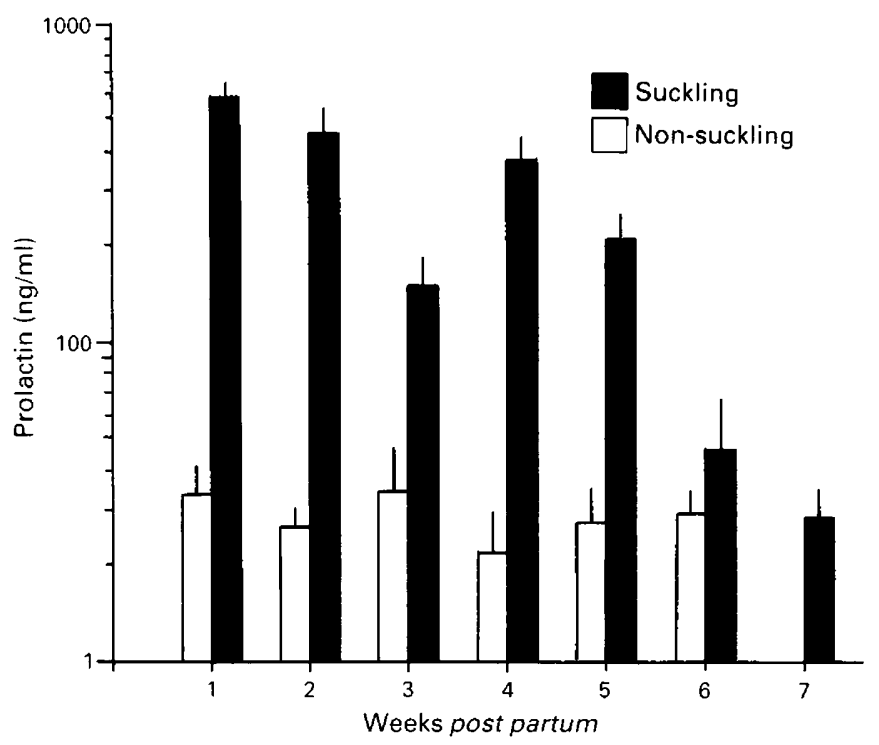

Fig. 5. Mean \pm s.e.m. prolactin concentrations in suckling and non-suckling ewes. Means were calculated from 19 blood samples collected at 20-min intervals weekly from Day 4 to Day 45 post partum.

amplitude (Figs $6 \& 7$ ) as seen in normal cyclic ewes immediately before the preovulatory LH surge (Fig. 3).

During the 3 days before an $\mathrm{LH}$ surge (i.e. during the follicular phase) the decrease in FSH concentrations was larger before a normal oestrous cycle than before a short cycle (Fig. 8).

In the ewe, a prolactin discharge occurs concurrently with the natural preovulatory surge of gonadotrophins (Reeves et al., 1970; Kann, 1971 a; Cumming et al., 1972; McNeilly, 1980) and with the oestrogen-induced LH surge (Fell et al., 1972; Davis \& Borger, 1974; Clarke et al., 1982; Howland et al., 1984). This discharge was difficult to detect in suckling ewes because of the blunting effect of suckling-induced hyperprolactinaemia and therefore could not be studied in these animals. 


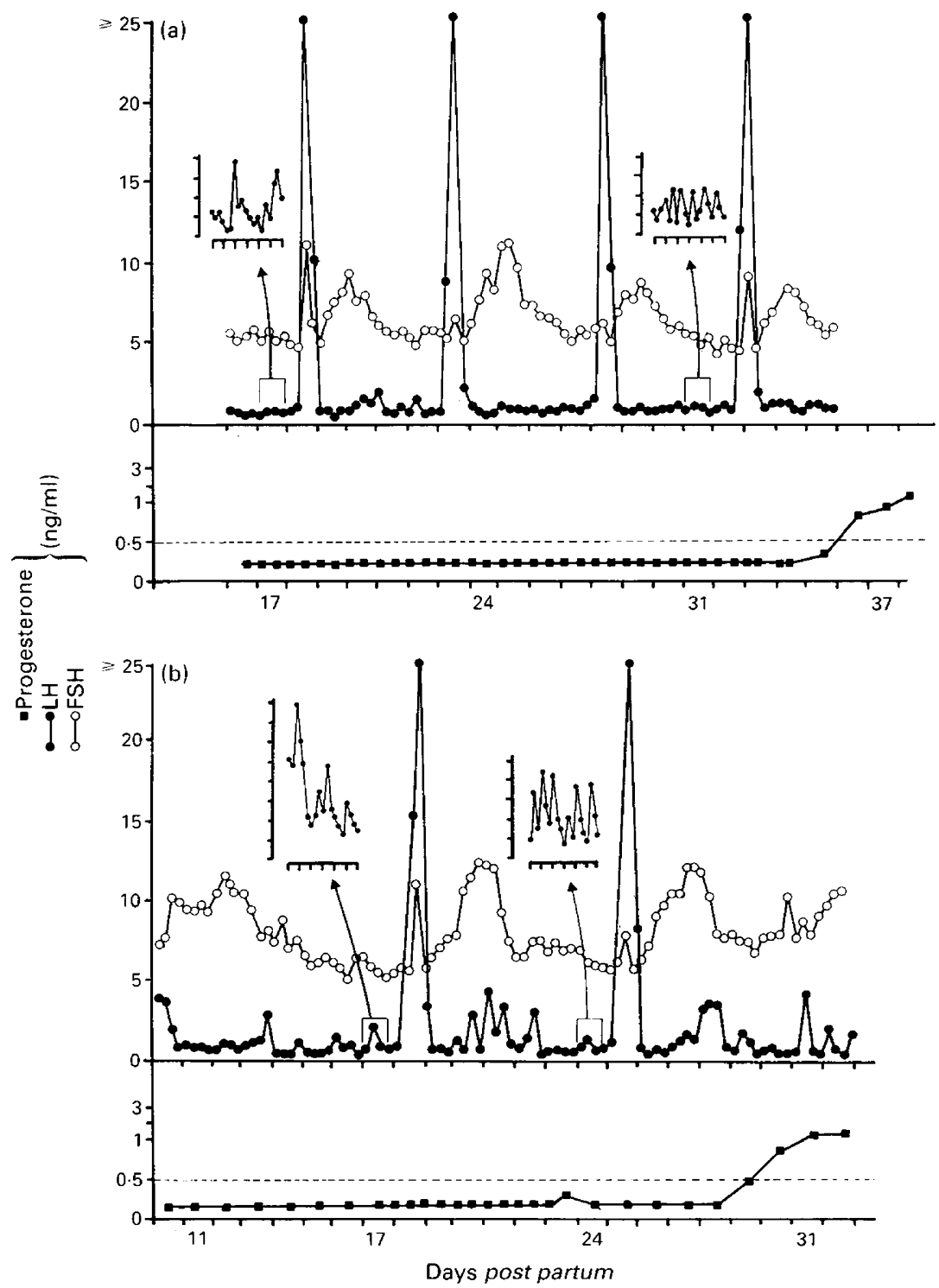

Fig. 6. Profiles of LH $(\bigcirc)$, FSH $(O)$ and progesterone $(\square)$ plasma concentrations in 1 nonsuckling ewe (a) and 1 suckling ewe (b) within 16-38 days after lambing. Notice the change in $\mathrm{LH}$ pulsatile secretion (insert) when serial blood samples were collected $24-36 \mathrm{~h}$ before the $\mathrm{LH}$ surges followed or not by the development of progesterone-secreting corpora lutea.

However, in 5/6 non-suckling ewes $\mathrm{LH}$ and prolactin surges were often desynchronized before the occurrence of a short cycle while they were not at the time of the establishment of a normal luteal phase (Fig. 9).

\section{Discussion}

This study clearly shows that after lambing there is a constant feature in the resumption of normal patterns of LH and FSH secretion: a rapid rise in FSH plasma concentrations which return to a 

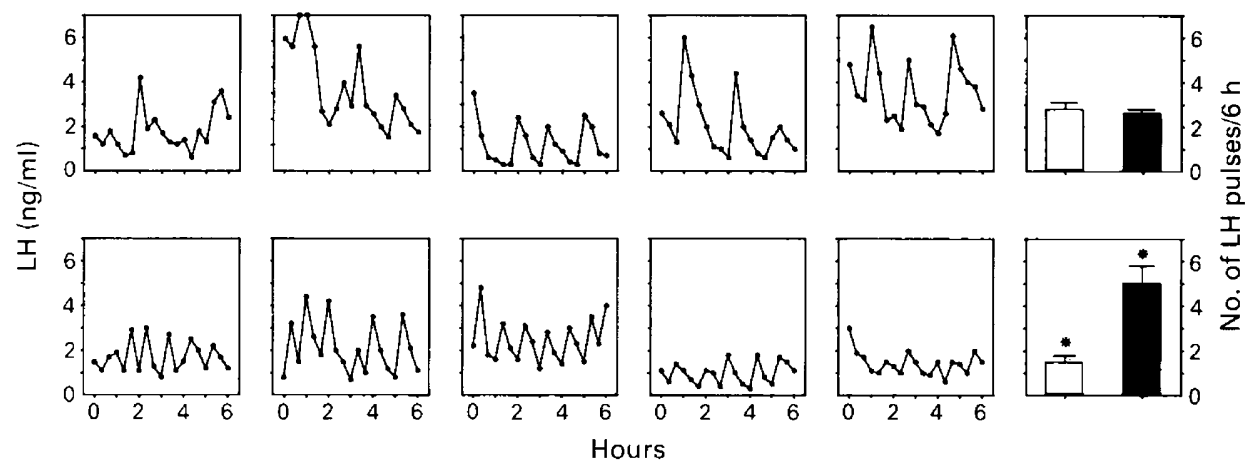

Fig. 7. Changes in frequency ( $\square$ ) and amplitude ( $\square$ ) of LH pulses within the $24.48 \mathrm{~h}$ preceding the first post-partum LH surge followed by a short cycle (top) and the subsequent LH surge followed by a normal cycle (bottom) in 5 ewes. *Significantly different $(P<0.05)$.

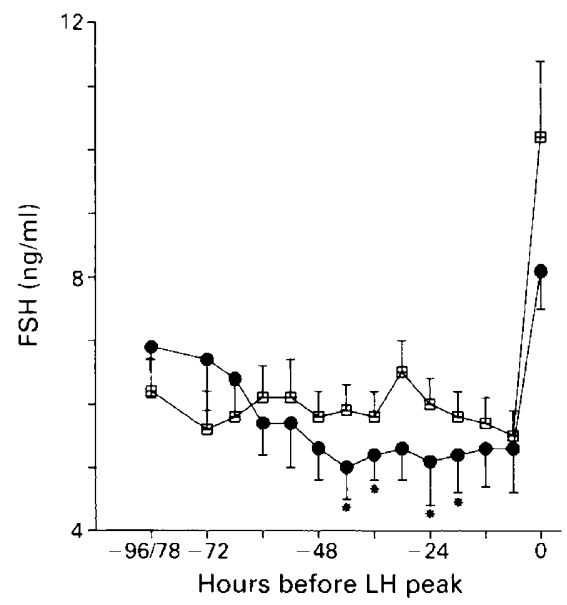

Fig. 8. Changes in mean \pm s.e.m. FSH concentrations within the $96 \mathrm{~h}$ preceding the first $\mathrm{LH}$ surge followed by a short cycle ( $\square$ ) and the subsequent LH surge followed by a normal cycle $(\bullet)$ in the same ewes as in Fig. 7. FSH concentrations were normalized on the peak value of LH surges (time 0$).{ }^{*}$ Significantly different from the period $96-78 \mathrm{~h}(P<0.05)$.

normal oestrous-cycle pattern of secretion as soon as Day 4-5 post partum both in suckling and non-suckling ewes; concurrently a more progressive increase in the frequency and amplitude of $\mathrm{LH}$ pulses especially in suckling ewes.

The rapid return of plasma FSH to normal oestrous-cycle levels after parturition suggests that the increase in FSH plasma concentrations might be brought about by the disappearance of placental oestrogens and/or of a placental inhibin-like factor. The presence of an inhibin-like material in the ewe placenta has not been demonstrated but inhibin-like bioactivity and immunoreactivity have been detected in human and rabbit placentas (McLachlan et al., 1986; Petraglia et al., 1987). It is unlikely that the early rise in FSH secretion may result from the resumption of pulsatile hypothalamic GnRH inputs to the pituitary gland. Effectively it is well established that FSH secretion requires minimal GnRH stimulation (Chappel et al., 1983; Clarke, 1989) and is mainly controlled by the negative feedback effects of steroids and peptides, principally inhibin (Ying, 1988). On the other hand, unlike in monkeys (Wildt et al., 1981), increasing GnRH pulse frequency 


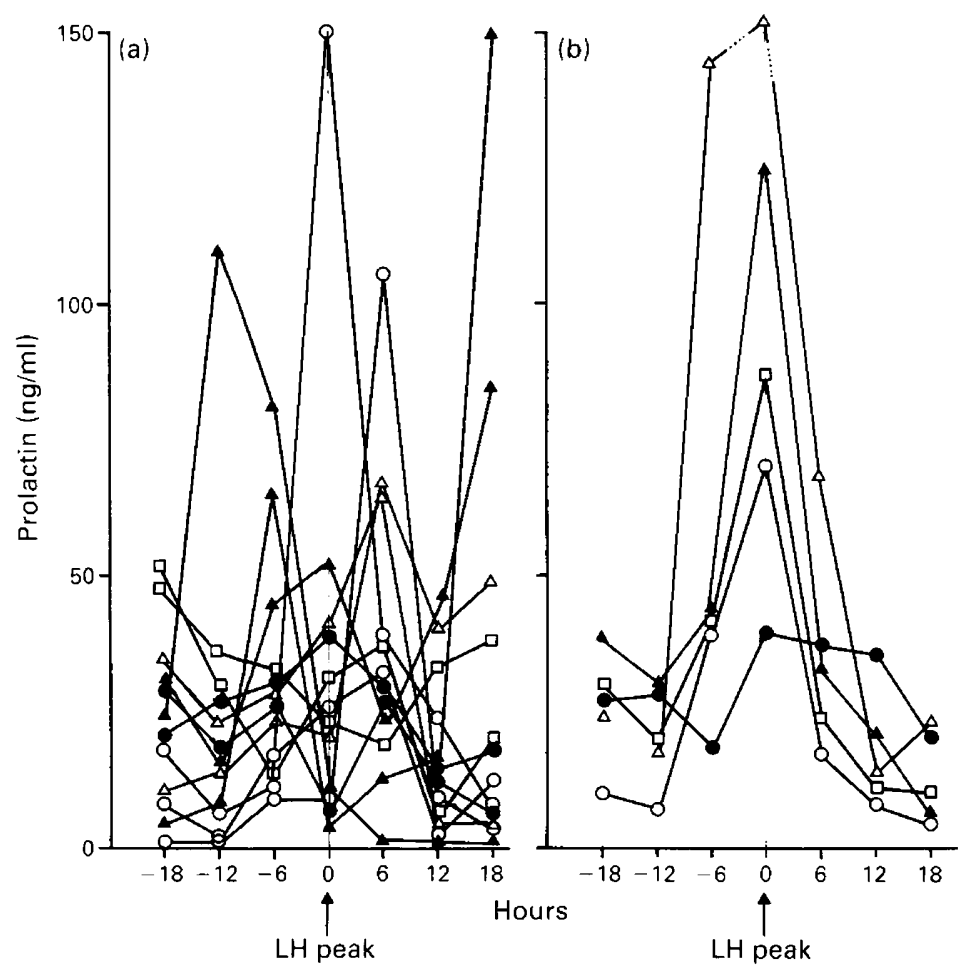

Fig. 9. Changes in plasma prolactin concentrations at the time of LH surges in 5 non-suckling ewes (one symbol per ewe) (a) before 3-4 consecutive short cycles; and (b) before the first normal luteal phase.

over a relatively short period of time in ovariectomized hypothalamo-pituitary-disconnected ewes did not lead to increased plasma levels of FSH (Clarke et al., 1984).

The early increase in FSH secretion explains that in the Préalpes du Sud ewes follicular development was observed as early as the first week post partum (Al-Gubory \& Martinet, 1986; Schirar, 1986). This rise in FSH is negatively correlated with the interval to the first LH surge post partum. This means that the faster the FSH concentrations increase after parturition, the faster the first LH surge resumes. It is also positively correlated with the interval to the first normal oestrous cycle. This relation is consistent with that previously established (Schirar et al., 1989a) between the interval to oestrus and the length of luteal phases and suggests that accelerated follicular growth after lambing might have deleterious effects on the subsequent ovarian function.

The subsequent undulating pattern of FSH secretion is attributable to effects of follicularovarian hormones. In effect, in earlier studies carried out in this laboratory on Préalpes du Sud ewes, laparotomy or endoscopy repeated at short intervals of time (5-7 days) in the same animal between Day 10 and Day 25 post partum showed that successive follicles develop to mature size and then regress until eventually one of these follicles ovulates (Schirar, 1986). This type of ovarian activity, not influenced by lactation, matches well the wave-like pattern of FSH secretion which has been well described in the ewe (Pant et al., 1977; Miller et al., 1981; Bister \& Paquay, 1983; Lalou-Kassi et al., 1984; Wheaton et al., 1984) and which was related to the successive waves of growing and regressing follicles (Coleman \& Dailey, 1983).

The progressive elevation of mean LH concentrations initially observed by Restall \& Starr (1977) is causally related to the resumption and increase in frequency of the pulsatile pattern of LH secretion. In the ewe this pulsatile pattern of LH secretion is an essential requirement not only for ovulation (Baird, 1978) but also for the onset and maintenance of ovarian cyclicity (Foster et al., 
1986; McNeilly et al., 1982; McLeod et al., 1982) and for the resumption of ovarian function after parturition (Wright et al., 1983, 1984). Moreover, since ovulation has been induced with LH alone (McNeilly et al., 1982), LH secretion appears to be one major factor limiting the resumption of normal ovarian function during the post-partum period.

Thus the absence of effect of suckling on the pattern of FSH and its retarding effect on the episodic pattern of LH secretion probably arise because suckling partly inhibits GnRH output.

The fact that the first post-partum LH surge resumes very early after parturition in some ewes attests that feed back mechanisms are operative. The observation that the first LH surges are of shorter duration is consistent with other investigations (Schirar, 1986) which showed that the positive feed-back effect of exogenous oestradiol-17 $\beta$ on LH secretion in intact and ovariectomized post-partum ewes is always present, but that the amplitude and duration of induced responses increase with the time elapsed from parturition and become similar to those observed in nonpost-partum ewes only after the 4th week post partum. Taken together these results suggest that functional recovery of the hypothalamic-hypophysial-ovarian axis is never complete before Day 25 post partum.

As suggested by Nett (1987) there are at least 2 steps in the resumption of LH secretion after parturition. There is first a recovery of pulsatile secretion of GnRH which allows LH concentrations to increase in the blood and pituitary content of LH to be restored rapidly. The frequency of LH pulses, however, is insufficient to induce full follicular maturation and so early ovulations are often followed by abnormal luteal function. Subsequently, the increased concentrations of LH continue to stimulate follicular growth and the resulting secretion of oestradiol. At this time the sensitivity to feed-back effects of the steroid is enhanced by the increased concentrations of hypothalamic and anterior pituitary gland receptors for oestradiol which occur after Day 20 post partum (Wise et al., 1986). Our opinion is that this improvement of oestradiol efficiency accounts for the change in the LH pulsatile pattern and the larger FSH decrease (Cognie et al., 1982; the present study) observed before the preovulatory surge at the time of resumption of normal oestrous cycles. Karsch et al. (1983) showed that this LH pattern is oestradiol-dependent. This change in LH secretion leads to the final stage of follicular growth and results after ovulation in the development of a corpus luteum with normal progesterone secretion. Prolactin does not seem to play a major role in this process and we do not know the biological significance of the re-establishment of synchronous LH and prolactin surges.

Finally, when one attempts to integrate post-partum endocrine function, it appears that resumption of regular oestrous cycles does not result solely from a delicately balanced secretion of gonadotrophins but also from the recovery of functional utero-ovarian relationships (Schirar et al., 1989 b) and the disappearance of some intra-ovarian regulators (Schirar \& Levasseur, 1989).

\section{References}

Al-Gubory, K.H. \& Martinet, J. (1986) Comparison of total follicular populations at day 140 of pregnancy and at day 5 postpartum in ewes. Theriogenology 25 , $795-808$.

Baird, D.T. (1978) Pulsatile secretion of LH and ovarian estradiol during the follicular phase of the sheep estrous cycle. Biol. Reprod. 18, 359-364.

Bister, J.L. \& Paquay, R. (1983) Fluctuations in the plasma levels of the follicle-stimulating hormone during estrous cycle, anestrus, gestation and lactation in the ewe: evidence for an endogenous rhythm of FSH release. Theriogenology 19, 565-579.

Blanc, M.R. \& Poirier, J.C. (1979) A new homologous radioimmunoassay for ovine follicle stimulating hormone; development and characterization. Annls Biol. anim. Biochim. Biophys. 19, 1011-1026.
Chamley, W.A., Jonas, H.E. \& Parr, R.A. (1976) Content of LH, FSH and growth hormone in the pituitaries of pregnant and anestrous sheep. Endocrinology' 98, $1535-1538$.

Chappel, S.C., Ulloa-Aguirre, A. \& Coutifaris, C. (1983) Biosynthesis and secretion of follicle-stimulating hormone. Endocr. Rev. 4, 179-211.

Clarke, I.J. (1989) The GnRH/gonadotropin axis in the ewe, cow and sow. Dom. Anim. Endocr. 6, 1-14.

Clarke, I.J., Funder, J.W. \& Findlay, J.K. (1982) Relationship between pituitary nuclear oestrogen receptors and the release of $\mathrm{LH}, \mathrm{FSH}$ and prolactin in the ewe. J. Reprod. Fert. 64, 355-362.

Clarke, I.J., Cummins, J.T., Findlay, J.K., Burman, K.J. \& Doughton, B.W. (1984) Effects on plasma luteinizing hormone and follicle-stimulating hormone of 
varying the frequency and amplitude of gonadotropin-releasing hormone pulses in ovariectomized ewes with hypothalamo-pituitary disconnection. Neuroendocrinology 39, 214-221.

Cognié, Y., Gayerie, G., Poulin, N. \& Saumande, J. (1982) Ovarian-pituitary dialogue during the postpartum period in the ewe. Curr. Top. Vet. Med. Anim. Sci. 20, 305-313.

Coleman, D.A. \& Dailey, R.A. (1983) Effects of repeated removal of large ovarian follicles and treatment with progestin on ovarian function in the ewe. Biol. Reprod. 29, 586-593.

Crowder, M.E., Gilles, P.A., Tamanini, C., Moss, G.E. \& Nett, T.M. (1982) Pituitary content of gonadotropins and $\mathrm{GnRH}$ receptors in pregnant, postpartum and steroid-treated ovx ewes. J. Anim. Sci. 54, 1235-1242.

Cumming, I.A., Brown, J.M., Goding, J.R., Bryant, G.D. \& Greenwood, F.C. (1972) Secretion of prolactin and luteinizing hormone at oestrus in the ewe. J. Endocr. 54, 207-213.

Davis, S.L. \& Borger, M.L. (1974) Dynamic changes in plasma prolactin, luteinizing hormone and growth hormone in ovariectomized ewes. J. Anim. Sci. 38, $795-802$.

Edgerton, L.A. (1980) Effect of lactation upon the postpartum interval. J. Anim. Sci. 51 (Suppl. 2), 40-52.

Fell, L.R., Beck, C., Brown, J.M., Catt, K.J., Cumming, I.A. \& Goding, J.R. (1972) Solid-phase radioimmunoassay of ovine prolactin in antibody-coated tubes. Prolactin secretion during estradiol treatment, at parturition, and during milking. Endocrinology 91, 1329-1336.

Fitzgerald, B.P. \& Cunningham, F.J. (198I) Effect of removal of lambs or treatment with bromocriptine on plasma concentrations of prolactin and FSH during the post-partum period in ewes lambing at different times during the breeding season. J. Reprod. Fert. 61, 141-148.

Foster, D.L., Karsch, F.J., Olster, D.H., Ryan, K.D. \& Yellon, S.M. (1986) Determinants of puberty in a seasonal breeder. Recent Prog. Horm. Res. 42, 331-383.

Howland, B.E., Sanford, L.M. \& Palmer, W.M. (1984) Serum concentrations of LH, FSH and prolactin in ovariectomized ewes following treatment with androgens or estrogens. Can. J. Anim. Sci. 64, $17 !-175$.

Kann, G. (1971a) Variations des concentrations plasmatiques de l'hormone lutéinisante et de la prolactine au cours du cycle oestrien chez la brebis. C. r. hebd. Séanc. Acad. Sci. Paris, D 272, 2934-2937.

Kann, G. (1971b) Dosage radio-immunologique de la prolactine plasmatique chez les ovins. $C$. $r$. hebd. Séanc. Acad. Sci. Paris D 272, 2808-2811.

Karsch, F.J., Foster, D.L., Bittman, E.L. \& Goodman, R.L. (1983) A role for estradiol in enhancing luteinizing hormone pulse frequency during the follicular phase of the estrous cycle of sheep. Endocrinology 113, 1333-1339.

Lalou-Kassi, A., Schams, D. \& Glatzel, P. (1984) Plasma gonadotrophin concentrations during the oestrous cycle and after ovariectomy in two breeds of sheep with low and high fecundity. J. Reprod. Fert. 70, 165-173.
Martin, G.B., Scaramuzzi, R.J. \& Henstridge, J.D. (1983) Effects of oestradiol, progesterone and androstenedione on the pulsatile secretion of luteinizing hormone in ovariectomized ewes during spring and autumn. J. Endocr. 96, 181-193.

McLachlan, I., Healy, D.L., Robertson, D.M., Burger, H.G. \& de Kretser, D.M. (1986) The human placenta: a novel source of inhibin. Biochem. Biophys. Res. Commun. 140, 485-490.

McLeod, B.J., Haresign, W. \& Lamming, G.E. (1982) Response of seasonally anoestrous ewes to smalldose multiple injections of $\mathrm{Gn}-\mathrm{RH}$ with and without progesterone pretreatment. $J$. Reprod. Fert. 65, 223-230.

McNeilly, A.S. (1980) Prolactin and control of gonadotrophin in the female. $J$. Reprod. Fert. 58, 537-549.

McNeilly, A.S., O'Connell, M. \& Baird, D.T. (1982) Induction of ovulation and normal luteal function by pulsed injections of luteinizing hormone in anoestrous ewes. Endocrinology 110, 1292-1299.

Miller, K.F., Nordheim, E.V. \& Ginther, O.J. (1981) Periodic fluctuations in FSH concentrations during the ovine oestrous cycle. Theriogenology 16, 669-679.

Moss, G.E., Adams, T.E., Niswender, G.D. \& Nett, T.M. (1980) Effects of parturition and suckling on concentrations of pituitary gonadotropins, hypothalamic GnRH and pituitary responsiveness to $\mathrm{GnRH}$ in ewes. J. Anim. Sci. 50, 496-502.

Nett, T.M. (1987) Function of hypothalamic-hypophysial axis during the post-partum period in ewes and cows. J. Reprod. Fert., Suppl. 34, 201-213.

Newton, G.R. \& Edgerton, L.A. (1989) Effect of season and lactation on luteinizing hormone secretion in postpartum ewes. Theriogenology 31, 885-893.

Palmer, E. \& Jousset, D. (1975) Urinary oestrogen and plasma progesterone levels in non-pregnant mares. $J$. Reprod. Fert., Suppl. 23, 213-221.

Pant, H.C., Hopkinson, C.R.N. \& Fitzpatrick, R.J. (1977) Concentration of oestradiol, progesterone, luteinizing hormone and follicle stimulating hormone in the jugular venous plasma of ewes during the oestrous cycle. J. Endocr. 73, 247-255.

Pelletier, J., Kann, G., Dolais, J. \& Rosselin, G. (1968) Dosage radio-immunologique de l'hormone lutéinisante plasmatique chez le mouton. Mise au point de la technique de dosage. C. r. hebd. Séanc. Acad. Sci. Paris D 266, 2291-2294.

Petraglia, F., Sawchenko, P., Lim, A.T.W., Rivier, J. \& Vale, W. (1987) Localization, secretion, and action of inhibin in human placenta. Science, NY 237, 187-189.

Reeves, J.J., Arimura, A. \& Schally, A.V. (1970) Serum levels of prolactin and luteinizing hormone (LH) in the ewe at various stages of the estrous cycle. Proc. Soc. exp. Biol. Med. 134, 938-942.

Restall, J. \& Starr, B.G. (1977) The influence of season of lambing and lactation on reproductive activity and plasma LH concentrations in Merino ewes. $J$. Reprod. Fert. 49, 297-303.

Schirar, A. (1986) L'anoestrus de lactation chez la brebis Préalpes du Sud. Reprise de l'activité gonadotrope hypothalamo-hypohysaire et de l'activité ovarienne. Thèse de Doctorat d'Etat es Sciences Naturelles. 84 pp. Université Paris VI.

Schirar, A. \& Levasseur, M.C. (1989) Resumption of ovarian activity in post-partum ewes: carry-over 
effect of the corpus luteum of pregnancy. Anim. Reprod. Sci. 19, 91-97.

Schirar, A., Cognié, Y., Louault, F., Poulin, N., Levasseur, M.C. \& Martinet, J. (1989a) Resumption of oestrous behaviour and cyclic ovarian activity in suckling and non-suckling ewes. J. Reprod. Fert. 87, 789-794.

Schirar, A., Meusnier, C., Paly, J., Levasseur, M.C. \& Martinet, J. (1989b) Resumption of ovarian activity in post-partum ewes: role of the uterus. Anim. Reprod. Sci. 19, 79-89.

Wagner, W.C. \& Oxenreider, S.L. (1971) Endocrine physiology following parturition. J. Anim. Sci. 32, I- 16.

Wettemann, R.P. (1980) Postpartum endocrine function of cattle, sheep and swine. J. Anim. Sci. 51 (Suppl. 2), 2-15.

Wheaton, J.E., Mullett, M.A. \& Cornelius, S.G. (1984) Plasma follicle stimulating hormone and luteinizing hormone patterns during the estrous cycle of the ewes. Theriogenology 21, 989-999.
Wildt, L., Hausler, A., Marshall, G., Hutchinson, J.S., Plant, T.M., Belchetz, P.E. \& Knobil, E. (198I) Frequency and amplitude of gonadotropin-releasing hormone stimulation and gonadotropin secretion in the rhesus monkey. Endocrinology 109, 376-385.

Wise, M.E., Glass, J.D. \& Nett, T.M. (1986) Changes in the concentration of hypothalamic and hypophyseal receptors for oestradiol in pregnant and post partum ewes. J. Anim. Sci. 62, 1021-1028.

Wright, P.J., Geytenbeek, P.E., Clarke, I.J. \& Findlay, J.K. (1983) LH release and luteal function in postpartum acyclic ewes after the pulsatile administration of LH-RH. J. Reprod. Fert. 67, 257-262.

Wright, P.J., Geytenbeek, P.E., Clarke, I.J. \& Findlay, J.K. (1984) Induction of plasma LH surges and normal luteal function in acyclic post-partum ewes by the pulsatile administration of LH-RH. J. Reprod. Fert. 71, 1-6.

Ying, S.Y. (1988) Inhibins, activins and follistatins: gonadal proteins modulating the secretion of folliclestimulating hormone. Endocrine Rev, 9, 267-293.

Received 30 June 1989 